\title{
Special aspects of 12-14 yrs children's psychological protection
}

\author{
Liashenko V.M., Tumanova V.M., Gnutova N.P., Gnutov E.I. \\ Borys Grinchenko Kyiv University, Kyiv, Ukraine
}

\begin{abstract}
Purpose:

Material: In the research children of 12 years $(n=5), 13$ years $(n=7)$ and 14 years $(n=13)$ participated.

Results: $\quad$ The greatest quantity of correlations was observed between compensation and hyper-compensation with other kinds of psychological protection. It was found that projection is the most frequently used by children psychological protection mechanism. It is observed in $76.7 \%$ of children. Second place is taken by refusal (50.9\%). On third place stands compensation (50\%) and hyper-compensation (50\%). The greatest quantity of interdependent correlations we received between compensation and other kinds of psychological protection (5 correlations) and projection (4 correlations).

Conclusions: Children's behavior can be regarded from the point of their emotional sphere, conscious and not conscious behavioral manifestations of this sphere. We give information to school psychologists about psychological everyday state of children. This information will help to understand the reason of de-adaptation or difficulties' emersion in children's life as well as permit to find appropriate means of work with problems and their correction.

Keywords: psychological protection, children, projection, compensation, rationalization, regression.
\end{abstract}

\section{Introduction}

Doctrine of psychological protection (or its mechanisms) belongs to classic psychoanalysis of $20^{\text {th }}$ century. Theoretical ideas of modern researchers base on ideas of Z. Freud and A. Freud [14, 15]. The representatives of this direction regarded psychological protection as the mean of solution the conflict between conscious and unconscious $[12,13,16,18]$. By opinion of some scientists $[6,7,1019]$, the most constructive psychological protection kinds are compensation and rationalization. The most destructive are projection and exclusion. With it, application of constructive protections reduces the risk of conflict or its aggravation.

A number of authors [2, 13, 24, 32] studied psychological protection mechanisms of adolescents with different behavioral styles in conflict. The authors determined that leading mechanisms of psychological protection are replacement and intellectualization. It is known that adolescents are in sensitive period of their growth. They are more flexible and adaptive, depending on situation.

The psychology of youth is one of important, interesting and insufficiently studied parts of age psychology. Peculiarities of this age depend on many factors: individual and social $[8,14,25,30]$. These distinctions are connected with reaching anatomicphysiological maturity by boys or girls; with new position in family or collective; with change of main activity type and need in solution the problem of professional selfdetermination $[11,15,28,31]$.

Prevalence of adolescents' expressed mechanism of refusal witnesses that in stress situation children can deny the circumstances of conflict. Such circumstances are evident for surrounding people but are not recognized bay a child [2]. D.A. Vasiuk studied such mechanism

\footnotetext{
(C) Liashenko V.M., Tumanova V.M., Gnutova N.P.,

Gnutov E.I., 2017
}

doi:10.15561/18189172.2017.0406 as "compensation" [2]. The author found correlations between personality's indicators such as: "irritation", "negativism" and "verbal aggression". The author affirms that compensation can be regarded as one of form of protection from inferiority complex. In adolescents it can be asocial behavior or aggressive criminal actions directed against personality [2].

With growing life experience special system is formed in a person, which protects him/her from information. It violates internal balance: the system of protective psychological barriers. However, psychological protection mechanisms can be more complex by structure $[3,17$, $22]$. That is why it is quite relevant to study and explain personality's changes, which take place in children for them to form personal protection strategy from inner conflicts and for their effective solution.

The purpose of the research is to analyze special aspects of 12-14 yrs children's psychological protection's manifestations.

\section{Material and methods}

Participants: the research was fulfilled in comprehensive secondary school №8 (Vasilkov). In the research children of 12-14 years age $(n=25)$ participated. All parents gave written consent for their children's participation if the research. The selected for research children formed one group.

Organization of the research: we used the questionnaire of Plutchik, Kellerman, Conte) - Life Style Index, LSI methodic [5, 20, 25], which is intended for diagnostic of mechanisms of psychological protection of "Self". The questionnaire consists of 97 questions, requiring answer "correct - not correct". Eight kinds of protection mechanisms are registered: exclusion, refusal, substitution, compensation, reactive formations, projection, intellectualization (rationalization) and regression. From 10 to 14 questions, describing human personalities reactions in different situations, correspond 
to every of these protection mechanisms. On the base of answers the profile of protection structure of the tested is built. We calculated the quantity of positive answers by every of 8 scales, according to key. The points were transformed in percents $[29,30]$. On the base of percent indicators we made the profile of EGO protections was created.

Statistical analysis: Student's t-test was used for determination of statistically significant differences of mean values. The data were processed with the help of Statistika-6 program.

\section{Results}

The questionnaire permits to study hierarchy of psychological protection system and its general tension. Let us regard characteristics of psychological protection typologies. As a result we received the following results:

Psychological mechanism "exclusion" implies active, motivated removal of something from conscious. As a rule it is manifested in the form of motivated forgetting or ignoring. Such psychological mechanism was observed in $47 \%$ of children. Excluded (inhibited) impulses preserve their emotional and psycho-vegetative components. For example, typical situation: meaningful side of psychotraumatizing situation is not realized. A child excludes the fact of bad action itself. But conflict still lives. The caused by it emotional tension subjectively is perceived as non motivated anxiety.

The next protection mechanism is "regression" (from Latin Regressus - backward movement). It means that child unconsciously starts practicing earlier, less mature and less adequate behavioral patterns. Child thinks that such behavior guarantees protection and safety. With such form of protection children undergo frustrating factors' impact. Children change solution of more difficult tasks to more feasible and simple. Such mechanism was observed in $39.5 \%$ of children.

Psychological protection mechanism "substitution" (sublimation) was observed in $37 \%$ of children. It means that a child seeks for sub-conscious substitute of one, prohibited (or practically not feasible) aim by other, able to satisfy his/her actual demand even partially.

For example, it can be open hate to classmate or towards senior, stronger schoolboy, which can result in undesirable conflict. That is why the hate is transferred to other person, weaker one. In most of cases substitution causes emotional tension, appeared under influence of frustrating situation. Substitution does not lead to emotional release or to achievement of the set aim. In such situation a child can realize unexpected, often senseless actions. Such actions can weaken inner tension.

Protection mechanism "refusal" is observed, when a child throws away thoughts, wishes, feelings, demands or realities. On conscious level the child can not take them; he/she does not want to put up with reality. Such mechanism is observed in $50.9 \%$ of children. The action of this mechanism means refusal of external reality aspects, which are not perceived by personality. But for other people these aspects are evident. It means that conflict takes place in child's consciousness, may be caused by information which threats child's self-preservation, selfrespect or social prestige.

In this group of children the most expressed psychological protection mechanism is "projection" (76.7\% of the tested). Projection implies the process, with the help of which not comprehended and not acceptable for personality feelings and thoughts are localized outside, being projected on other people. Thus, they become, so to say, secondary. Negative and asocial tint of the endured feelings and features is projected on surrounding people. It becomes an excuse of own aggressiveness or unfriendliness, manifested as if for protection.

Protection mechanism "compensation" takes third position among the tested (50\%). It means "correction" of own, real or imaginable physical or psychic inferiority. Often such mechanism is combined with identification. It implies attempts to find appropriate substitute (other quality) of real or imaginable drawback; defect or unbearable feeling. The most often it is achieved by fantasizing or assignment of features, values, behavior characteristics or advantages of other personality.

In other case the next manifestation is possible physically weak or fearful child is not able to meet the threat of violence. Then, he/she satisfies with humiliation of abuser with the help of fine mind or slyness. Such children often are dreamers, who seek their ideals in different life activities.

"Hyper-compensation" means substitution of real or imaginable psychological inferiority by high achievements in other spheres of activity.

This mechanism is observed in $50 \%$ of children. Probable manifestation of this mechanism is explained in the following way: children avoid unpleasant or not acceptable for them thoughts, feelings or actions by excessive development of opposite features.

The final psychological mechanism is "rationalization". It implies logical explanation own thoughts, actions and feelings by a child. It permits for him/her to excuse and hide actual motives.

Such mechanism is observed in $49 \%$ of children. In conflict situation child weakens significance of reasons, which caused this conflict or psycho-traumatizing situation. дітей.

In scale of intellectualization we also included sublimation. It is a mechanism of psychological protection, in which the excluded wishes and feelings are compensated by higher social values.

We received the following results: the greatest quantity of correlations was registered between compensation and other kinds of psychological protection (5 correlations, significance level $\mathrm{p}<0.05$ ) and projection (4 correlations at $\mathrm{p}<0.05)$.

Psychological protection of personality acts as a system. Such protection acts according to age and other possible factors. Advantage of such kinds of protection is evident. It is observed more frequently than other kinds. 


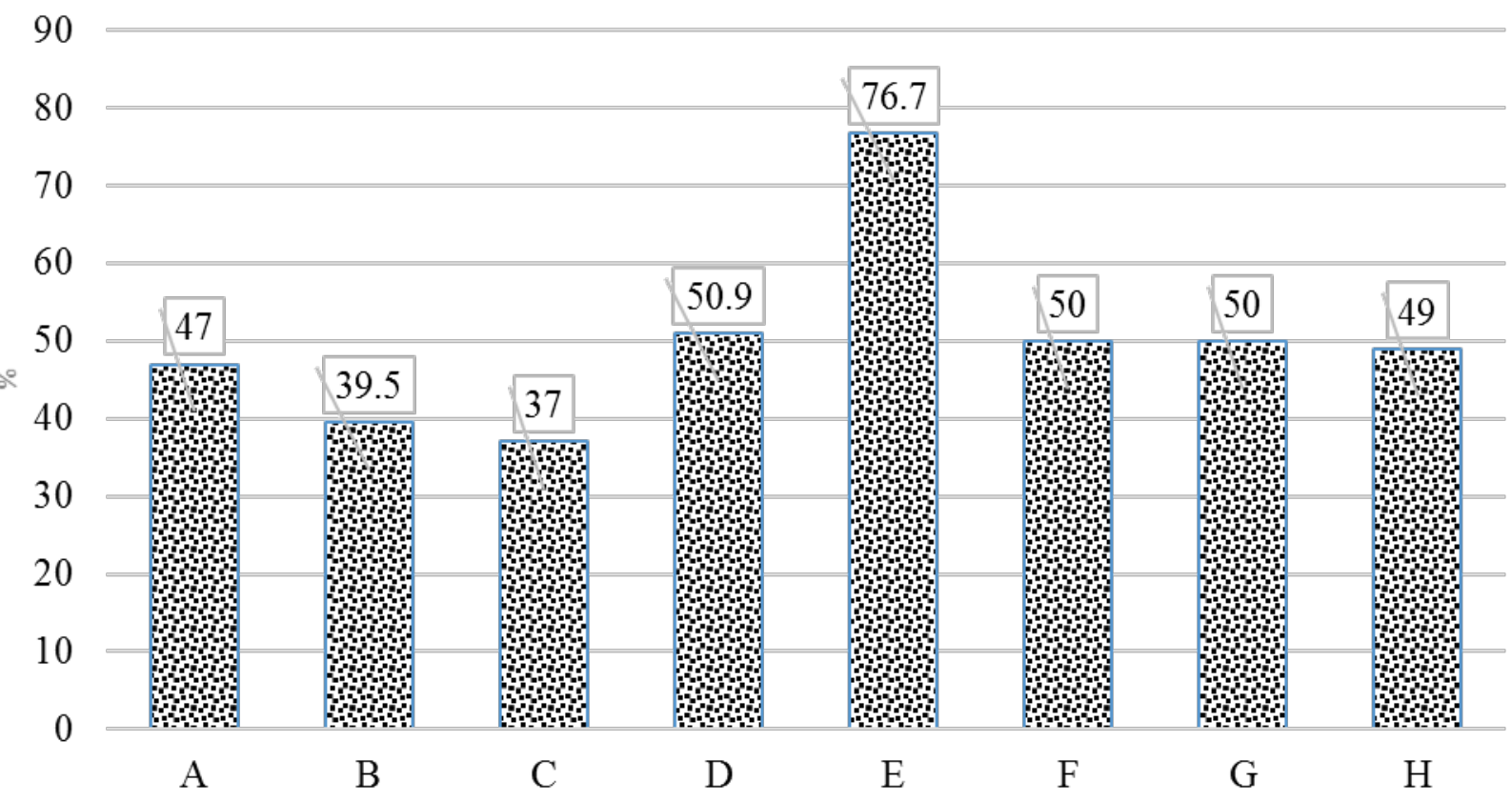

Fig. 1. Mechanisms of children's psychological protection: A- exclusion; B - regression; C-substitution; D - refusal; I projection; $\mathrm{F}$ - compensation; $\mathrm{G}$ - hyper-compensation; $\mathrm{H}$ - rationalization.

Table. Kinds of psychological protection

\begin{tabular}{|c|c|c|c|c|c|c|c|c|}
\hline \multirow{2}{*}{$\begin{array}{l}\text { Kinds of } \\
\text { psychological } \\
\text { protection }\end{array}$} & \multicolumn{8}{|c|}{ Kinds of psychological protection } \\
\hline & Refusal & Exclusion & Regression & Compensation & Projection & Substitution & Rationalization & $\begin{array}{l}\text { Reactive } \\
\text { formations }\end{array}$ \\
\hline Refusal & 1.00 & & & $0.49 *$ & $0.48^{*}$ & & & \\
\hline Exclusion & & 1.00 & & & & & & \\
\hline Regression & & $0.44^{*}$ & 1.00 & $0.52 *$ & & & & \\
\hline Compensation & $0.49 *$ & & $0.52^{*}$ & 1.00 & $0.57^{*}$ & & $0.66^{*}$ & $0.47^{*}$ \\
\hline Projection & $0.48^{*}$ & & & $0.57^{*}$ & 1.00 & $0.51 *$ & & $0.53 *$ \\
\hline Substitution & & & & & $0.51^{*}$ & 1.00 & & \\
\hline Rationalization & & & & $0.66^{*}$ & & & 1.00 & \\
\hline $\begin{array}{l}\text { Reactive } \\
\text { formations }\end{array}$ & & & & $0.47^{*}$ & $0.53^{*}$ & & & 1.00 \\
\hline
\end{tabular}

Notes: ${ }^{*}$ - correlation coefficient is significant at $r=0.41$, with $p<0.05$ (with $n=25$ persons).

\section{Discussion}

As per the data of some authors [7, 11] among boys the leading protections are exclusion and rationalization. Such personality's features and actions, which do not make personality more attractive in own eyes and in eyes of other people: envy, unfriendliness, ingratitude and etc., are excluded the most often $[13,23]$. With rationalization personality creates logical grounds of own or other's behavior, actions or feelings. It is caused by reasons, which the personality can not accept or he/she will loose self respect. Such kind of protection can result in evident attempts to weaken the value of not feasible experience.

As it was mentioned above, exclusion is a destructive kind of protection. It is used mainly by adolescents. In our study such mechanisms take fifth and sixth place.

In our work we proved the data about the most expressed psychological protection mechanism in 12-14 yrs children (projection). Unfortunately, some authors [7, $11,34]$ think that projection is one of destructive forms of psychological protection. Its application reduces the risk of conflicts. In general examples and cases, when children attribute to other people own amoral whishes, are well known. For example: amoral actions are realized by classmates; home task is difficult because teacher insufficiently explained this exercise. Other kind of projection, when surrounding people are attributed with positive, socially good thoughts or action, is more seldom.

With the help of refusal personality refuses some frustrating circumstances or some internal impulses. It takes the second place in schoolchildren. Our data coincide with the data of other study [2]. Very often children do not want to perceive information, which they dislike. In the future they even can not recall that they met it. It is thrown away as unnecessary without any trace in mind. 
Though, this kind of psychological protection has not been paid sufficient attention by many authors. But a number of other authors reasonably thinks [11,33], that compensation can be regarded as a form of protection from inferiority complex. For example it concerns adolescents with asocial behavior, with aggressive and criminal actions against personality.

Mechanism of substitution implies release of heavy emotions (as a rule hostility and anger), which are directed to less dangerous or to more feasible objects. By our observations adolescents do not use this mechanism frequently (37\%). But our data differ from the data of other scientists [2, 13, 21, 27]. Self-consciousness is still being formed in adolescents' age. That is why plasticity of psych conditions different response too frustrating circumstances. Our data demonstrate variability in application of psychological protections and are the novelty in respect to the chosen contingent of children.

\section{Conclusions}

It was found that the most frequently children use psychological protection mechanism "projection". It is observed in $76.7 \%$ of children. Second place is taken by "refusal" (50.9\%); third place - by "compensation" $(50 \%)$ and "hyper-compensation" (50\%). Information about psychological protection and special aspects of personality are of great value. Children's behavior can be regarded from the point of their emotional sphere, conscious and unconscious behavioral manifestations of this sphere. We give information about children's "everyday psychological status" to school psychologists. In the nearest future such children will independently solve life and professional tasks. That is why the provided by us information can help to understand the reasons of de-adaptation of difficulties in solution of life problems. Besides, it will help to find appropriate means of work with problems and their correction.

\section{Conflict of interests}

The authors declare that there is no conflict of interests.

\section{References}

1. Vasiuk DA. Study of protection mechanisms and forms of adolescents' aggressive behavior. Koncept, 2014;26:246250. (in Ukrainian)

2. Golovinova AV, Ovsiannikova EA. Mechanisms of psychological protection of adolescents with different behavioral styles in conflict. Nauka i Sovremennost' 2011;1:46-54. (in Russian)

3. Granovskaia RM. Elements of practical psychology, Sankt Petersburg: Speech; 2003. (in Russian)

4. Docenko EL. Psychology of manipulation. Sankt Petersburg: Speech; 2004. (in Russian)

5. Kruzhkova OV, Shakhmatova ON. Psychological protections of personality, Ekaterinburg; 2006. (in Russian)

6. Kriukova TL. Psychology of controlled behavior, Kostroma: Avantitul Operational Printing Studio; 2004. (in Russian)

7. Lapkina EV. Psychological protection and control. Iaroslavskij pedagogicheskij vestnik. 2011;2: 232 - 236. (in Russian)

8. Miasishchev VN. Psychology of relations] Moscow: MPSI; 2003. (in Russian)

9. Sergienko EA, Kriukova TL. Psychology of controlled behavior, Kostroma: KSU; 2007. (in Russian)

10.Troickaia KK. Special aspects of psychology of senior adolescent and youngster, Leningrad; 1973. (in Russian)

11.Tulup'eva TV. Psychological protection and personalities features in early youth, Sankt Petersburg: SPbSU; 2000. (in Russian)

12.Tulup'eva TV, Tulup'ev AL, Nikolenko SI, Pashchenko AE, Abramian MK, Iastrebova EL, Stoliarova EV, Rybkina ZI. Psychological protection and personalities features in youth age, Trudy SPIIRAN, 2006;3(2): 224 -243. (in Russian)

13.Chernenko VG, Golovina SG. Special aspects of psychological protection mechanisms in primary school age children. In: $15^{\text {th }}$ international scientific-practical conference "Personality, family and society: the problems of pedagogic and psychology", Novosibirsk: Sibak; 2012;2:110 -115. (in Russian)

14.Frejd Z. Introduction to psychoanalysis, Moscow: Science; 1989. (in Russian)
15.Frejd A. EGO and protection mechanisms. Moscow: Eksmo; 2003. (in Russian)

16.Aydin B, Akbas S, Turla A, Dundar C. Depression and posttraumatic stress disorder in child victims of sexual abuse: perceived social support as a protection factor. Nordic Journal of Psychiatry. 2016;70(6):418-23.

17.Druz VA, Iermakov SS, Nosko MO, Shesterova LYe, Novitskaya NA. The problems of students' physical training individualization. Pedagogics, psychology, medicalbiological problems of physical training and sports, 2017; 21(2): 51-59. doi:10.15561/18189172.2017.0201

18.Fletcher AC, Buehler C, Buchanan CM, Weymouth BB. Parenting stressors and young adolescents' depressive symptoms: Does high vagal suppression offer protection? Physiology \& Behavior. 2017;170:78-87.

19.Gariepy G, Honkaniemi H, Quesnel-Vallee A. Social support and protection from depression: systematic review of current findings in Western countries. British Journal of Psychiatry. 2016;209(4):286-95.

20.Hyphantis T, Floros GD, Goulia P, Iconomou G, Assimakopoulos K. [The Life Style Index: correlations with psychological distress and hostility]. Psychiatriki. 2011;22(3):207-20.

21.Hyphantis T, Goulia P, Floros GD, Iconomou G, Pappas A-I, Karaivazoglou K, et al. Assessing Ego Defense Mechanisms by Questionnaire: Psychometric Properties and Psychopathological Correlates of the Greek Version of the Plutchik's Life Style Index. Journal of Personality Assessment. 2011;93(6):605-17.

22.Iermakov SS, Podrigalo LV, Jagiello W. Hand-grip strength as an indicator for predicting the success in martial arts athletes. Archives of Budo. 2016;12:179-86.

23.Kaleta D, Makowiec-Dabrowska T, Jegier A. Lifestyle index and work ability. Int $J$ Occup Med Environ Health. 2006;19(3):170-7.

24.Kaljee L, Zhang LY, Langhaug L, Munjile K, Tembo S, Menon A, et al. A randomized-control trial for the teachers' diploma programme on psychosocial care, support and protection in Zambian government primary schools. Psychology Health \& Medicine. 2017;22(4):381-92. 
25.Lang C, Feldmeth AK, Brand S, Holsboer-Trachsler E, Puhse $\mathrm{U}$, Gerber M. Effects of a physical education-based coping training on adolescents' coping skills, stress perceptions and quality of sleep. Physical Education and Sport Pedagogy. 2017;22(3):213-30.

26.Lazarus RS, Folkman S. Stress, appraisal, and coping. N.Y.: Springer Publishing; 1984.

27.Lenz TL, Gillespie ND, Skradski JJ, Viereck LK, Packard KA, Monaghan MS. Development of a Composite Lifestyle Index and Its Relationship to Quality of Life Improvement: The CLI Pilot Study. ISRN Preventive Medicine. 2013;2013:1-7.

28.Lin WF, Lin YC, Huang CL, Chen LH. We Can Make It Better: "We" Moderates the Relationship Between a Compromising Style in Interpersonal Conflict and Well-Being. Journal of Happiness Studies. 2016;17(1):41-57.

29.Plutchik R, Conte H.R. Measuring emotions and their derivatives: Personality traits, ego defenses and coping styles. In: Wetzler S, Katz M. (Eds.), Contemporary approaches to psychological assessment. N.Y.: Brunner/Mazel; 1989. P. 239-269.

30.Plutchik R, Kellerman H, Conte HR. A structural theory of ego defenses and emotions. In: Izard C. Emotions in personality and psychopathology. New York: Plenum Press; 1979. P. 229-257.

31.Pryimakov AA, Eider E, Nosko MO, Iermakov SS. Reliability of functioning and reserves of system, controlling movements with different coordination structure of special health group girl students in physical education process. Physical education of students, 2017; 21(2): 84-89. doi:10.15561/20755279.2017.0206

32.Roman NV, Davids EL, Moyo A, Schilder L, Lacante M, Lens W. Parenting styles and psychological needs influences on adolescent life goals and aspirations in a South African setting. Journal of Psychology in Africa. 2015;25(4):305-12.

33.Zautra AJ, Burleson MH, Smith CA, Blalock SJ, Wallston KA, DeVellis RF, DeVellis BM, Smith TW. Arthritis and perceptions of quality of life: An examination of positive and negative affect in rheumatoid arthritis patients. Health Psychology. 1995; 1:399-408.

34. Ortimore P. The positive effects of schooling. In: Rutter M, ed. Psychosocial disturbances in young people: challenges for prevention. Cambridge: Cambridge University Press; 2001.

\section{Information about the authors:}

Liashenko V.M.; http://orcid.org/0000-0002-4835-1390; v.liashenko@kubg.edu.ua; Borys Grinchenko Kyiv University; 18/2 BulvarnoKudriavska Str, Kyiv, 04053, Ukraine.

Tumanova N.M.; http://orcid.org/0000-0002-9838-6081; v.tumanova@kubg.edu.ua; Borys Grinchenko Kyiv University; 18/2 Bulvarno-Kudriavska Str, Kyiv, 04053, Ukraine.

Gnutova N.P.; http://orcid.org/0000-0002-1756-6479; n.hnutova@kubg.edu.ua; Borys Grinchenko Kyiv University; 18/2 BulvarnoKudriavska Str, Kyiv, 04053, Ukraine.

Gnutov E.I.; http://orcid.org/0000-0001-9076-3252; y.hnutov@kubg.edu.ua; Borys Grinchenko Kyiv University; 18/2 BulvarnoKudriavska Str, Kyiv, 04053, Ukraine.

Cite this article as: Liashenko VM, Tumanova VM, Gnutova NP, Gnutov EI. Special aspects of 12-14 yrs children's psychological protection. Pedagogics, psychology, medical-biological problems of physical training and sports, 2017;21(4):180-184. doi:10.15561/18189172.2017.0406

The electronic version of this article is the complete one and can be found online at: http://www.sportpedagogy.org.ua/index.php/PPS/issue/archive

This is an Open Access article distributed under the terms of the Creative Commons Attribution License, which permits unrestricted use, distribution, and reproduction in any medium, provided the original work is properly cited (http://creativecommons.org/licenses/by/4.0/deed.en).

Received: 22.03 .2017

Accepted: 05.04.2017; Published: 30.08.2017 